\title{
Percepções de justiça social e atitudes de estudantes pré-vestibulandos e universitários sobre as cotas para negros e pardos nas universidades públicas
}

\author{
Paulo S. C. Neves \\ Universidade Federal de Sergipe, Pós-Graduação em Educação e em Ciências Sociais \\ Marcus Eugênio O. Lima \\ Universidade Federal de Sergipe, Curso de Psicologia e Mestrado em Sociologia
}

\section{Introdução}

Um dos eixos mais inovadores das políticas públicas brasileiras dos últimos anos tem sido a adoção de políticas afirmativas voltadas para a diminuição de diferenças socioeconômicas entre algumas categorias sociais. Essas políticas estão pautadas na idéia de que, para garantir a igualdade de direitos, é necessária a ação do Estado no sentido de oferecer condições especiais àqueles que, por razões de ordem social, econômica, cultural ou política, estão originalmente em situação desfavorável de competição com outros membros da sociedade.

Assim, durante os últimos anos, diversas ações governamentais, de instituições públicas e de empresas privadas, têm sido implementadas, tais como o estabelecimento da obrigatoriedade de $50 \%$ de mulheres nas candidaturas para cargos políticos eletivos, a implantação de políticas educativas específicas para indígenas, a adoção por alguns órgãos públicos de condições de acesso privilegiadas para afrodescendentes, a obrigatoriedade imposta às empresas de contratação de um percentual mínimo de portadores de deficiência física etc.
Porém, se essas medidas têm sido implantadas em um clima relativamente consensual, o mesmo não ocorre com relação às cotas para afrodescendentes nas universidades públicas, objeto de viva polêmica. Isso, por si só, parece ser um sintoma da dificuldade de discutir as desigualdades baseadas na origem étnicoracial no país.

No entanto, embora muitos discordem da necessidade de implantação de uma política de cotas para afrodescendentes, certo consenso formou-se sobre a forte relação entre desigualdades socioeconômicas e origem étnico-racial ${ }^{1}$ no Brasil. As mais diversas estatísticas a esse respeito são categóricas: de qualquer ponto de vista e de qualquer dimensão analítica é patente a assimetria entre a situação dos brancos e dos não-brancos, os não-brancos ocupando sistematicamente as posições mais baixas da escala social. Os

\footnotetext{
${ }^{1}$ Adotamos aqui o ponto de vista de Banton (1977) e Guima-
} rães (1999), segundo o qual, embora as raças não existam em termos biológicos, podem, em certas sociedades, ter uma existência social. Isso se dá na medida em que o conceito de raça faz parte dos valores e crenças socialmente partilhadas dessas sociedades. 
negros têm menos acesso à educação, à renda e à moradia do que os "brancos" (INSPIR, 1999), possuem piores empregos (Lovell, 1994) e são maioria entre os desempregados (INSPIR, 1999). As mulheres negras têm no emprego doméstico a principal forma de inserção profissional (90\% das empregadas domésticas são negras), trabalham mais tempo e recebem menores salários do que as mulheres brancas (Patai, 1988). Os negros são, ainda, os que possuem as mais altas taxas de mortalidade infantil e menor expectativa de vida (Wood \& Lovell, 1992); além de serem os que menos acesso têm às universidades (Turra \& Venturi, 1995) e que apresentam mais baixa mobilidade social (Hasenbalg, 1979, 1985). São discriminados também no acesso à justiça penal (Adorno, 1996) e no modo como são retratados nos livros didáticos (Silva, 2001).

As conseqüências dessas várias formas de discriminação fazem-se sentir também no plano da autoestima da população de origem negra. França e Monteiro (2002), estudando a autoclassificação da cor e a identidade étnica em crianças negras de 5 a 10 anos de idade em Aracaju, verificaram uma tendência à negação da identidade negra e uma fuga para o "branqueamento". Sansone (2004) obtém dados semelhantes com adultos na Bahia, fato que já havia sido detectado por Bastide e Fernandes (1959) nos anos de 1950 em São Paulo.

As causas desse fenômeno são de ordem histórica e sociocultural. A pesada herança escravocrata, aliada às características perversas do preconceito racial no país, terminaram por criar uma série de dificuldades para a integração social e econômica dos nãobrancos. Com isso, não seria exagerado afirmarmos que a cidadania no Brasil caminha a duas velocidades distintas: uma, que concerne majoritariamente aos brancos, ao passo da modernidade; e a outra, que diz respeito principalmente aos não-brancos, marcada pela ausência da cidadania social.

Apesar disso, o Brasil foi muitas vezes percebido como um país sem preconceito racial, onde "negros", "pardos", "amarelos", "índios" e "brancos" conviveriam harmoniosamente e onde todos seriam tratados como iguais. Durante muito tempo essa foi a imagem construída e a visão predominante sobre o caráter peculiar das relações raciais no Brasil. ${ }^{2}$ De fato, depois da abolição da escravidão, em 1888, nunca tivemos um regime tão abertamente violento e segregacionista como o Jim Crow americano ${ }^{3}$ ou o apartheid da África do Sul. Como argumenta Guimarães (1999), o modelo de relações raciais no Brasil pós-abolição, ao contrário, mostrava uma sutil etiqueta de distanciamento social e uma diferenciação aguda no estatuto e nas possibilidades econômicas entre "brancos" e "não-brancos", convivendo com igualdade jurídica e indiferenciação formal. Ou seja, desde o fim da escravidão as expressões do preconceito racial apresentaram-se de maneira sutil ou velada (Munanga, 1996), e desde muito cedo o preconceito racial brasileiro caracteriza-se pelo "preconceito de ter preconceito" (Fernandes, 1966).

Assim, malgrado o discurso da democracia racial estar ainda presente no imaginário nacional, o que diversos estudos no campo das ciências humanas têm demonstrado é que, embora formalmente o preconceito racial à brasileira possa revestir-se de certa sutileza e certo distanciamento social, ele atua de forma violentamente discriminatória contra os grupos racializados.

A consciência dessa problemática emergiu com força na sociedade brasileira a partir dos anos de 1970, quando se constitui um movimento social capaz de di-

${ }^{2}$ Visão que se vai desenvolver no Brasil a partir dos trabalhos de Gilberto Freyre (1933), que considerava a sociedade brasileira como uma verdadeira democracia racial. Essa tese vai ser retomada pelas elites políticas que ascendem ao poder com a Revolução de 1930, e vai tornar-se um dos elementos discursivos mais importantes da ideologia nacional no país. Desde os anos de 1950, porém, essa visão idílica convive com interpretações alternativas sobre as relações raciais no país, como podemos ver nos trabalhos de diversos autores das ciências humanas: Bastide e Fernandes (1959), Fernandes (1966), Azevedo (1996), Ramos (1951), Nogueira (1983, 1998), entre outros.

${ }^{3}$ Para uma discussão terminológica, ver Wilson (2001). 
fundir o discurso anti-racista no país (Cardoso, 1987; Nascimento \& Nascimento, 2000), o qual vai influenciar a agenda pública no sentido da implantação de medidas visando transformar a realidade das populações não-brancas: da criação de delegacias especializadas para investigar as denúncias de racismo à adoção de políticas públicas visando à integração dos negros e pardos no mercado de trabalho; do reconhecimento do direito à terra para comunidades remanescentes de quilombos à obrigatoriedade de conteúdos ligados à história da África nos livros didáticos etc.

São, contudo, as ações que visam facilitar o acesso dos não-brancos aos cursos superiores que são vistas como portadoras de efeitos mais duradouros e eficazes na quebra do círculo vicioso da exclusão da população negro-mestiça. Ainda que as cotas de acesso às universidades tenham assumido o primeiro plano do debate público, elas não são as únicas medidas implementadas. O leque das propostas vai de cursos pré-vestibulares gratuitos para populações carentes e pobres à adoção de bolsas de estudos para estudantes negros etc. No que se refere às cotas, elas foram inicialmente postas em aplicação por algumas universidades isoladas (a exemplo das estaduais do Rio de Janeiro e da Bahia, da Universidade de Brasília UnB), expandindo-se gradualmente para outras universidades até serem integradas na proposta de reforma universitária do governo federal e em projetos de leis tais como o Estatuto da Igualdade Racial.

Como vimos, essas medidas vão gerar uma grande polêmica acerca não só do princípio da igualdade de chances no país, mas também sobre as repercussões para a qualidade de ensino e para a vida universitária de uma maneira geral. Debate que se aprofundou com a intenção do governo federal de transformar em lei a proposta de implantação nas universidades públicas federais, em seus vestibulares, do sistema de cotas para afrodescendentes. O que é patente nos manifestos recentemente publicados na imprensa, com assinaturas de intelectuais e homens públicos contra e a favor das cotas universitárias para afrodescendentes.

Contudo, se a maneira como as cotas são percebidas pela população em geral começa a ser investi- gada, o mesmo não se dá com relação ao que pensa a comunidade universitária das universidades públicas. Ora, se é verdade que, como mostram algumas pesquisas nacionais, a opinião pública está tornando-se favorável às cotas, ${ }^{4}$ sem investigarmos como elas são percebidas em estados diferentes e pelos grupos que compõem o mundo universitário, teremos dificuldades para entender por que em algumas regiões as cotas já foram implementadas nas universidades e em outras há maiores resistências.

Nesse sentido, podemos afirmar que a polêmica em torno da questão tem sido tão intensa que a discussão sobre os possíveis benefícios e malefícios da implantação das cotas se fez de forma abstrata, sem uma preocupação com a percepção social sobre elas.

Neste texto partimos de um ponto de vista diverso. Nosso intuito aqui não é tanto discutir as conseqüências positivas ou negativas das cotas, mas, antes, nos interrogarmos sobre a forma como as cotas são percebidas por alguns setores da população diretamente implicados com a sua adoção. Isso se justifica na medida em que, se a implantação das cotas nas universidades está difundindo-se, as resistências às elas não parecem estar decrescendo. Então, como compreender a contradição aparente entre o reconhecimento quase unânime da influência negativa da discriminação racial sobre as possibilidades de ascensão social dos afro-brasileiros e a rejeição de alguns setores sociais ao sistema de cotas raciais nas universidades públicas? A questão, assim colocada, traz

${ }^{4}$ É o que sinalizam algumas pesquisas nacionais de opinião recentemente publicadas: pesquisa realizada pelo Instituto Brasileiro de Opinião Pública e Estatística (IBOPE) em fevereiro de 2006 mostrava que 53\% da população brasileira era favorável às cotas para estudantes de escolas públicas, e apenas 33\% apoiava as cotas para negros e pardos (Globo on line, 9 fev. 2006); já em pesquisa do Datafolha publicada no jornal Folha de S.Paulo de 23 jul. 2006, 65\% dos entrevistados são favoráveis ao Estatuto da Igualdade Racial, que prevê $20 \%$ das cotas para negros e pardos nas universidades públicas. Ou seja, o debate sobre as cotas parece estar influenciando a sua aceitação no conjunto da população. 
à tona uma discussão tanto sobre as potencialidades das cotas, quanto sobre suas lógicas internas de justificação.

Desse modo, para um melhor entendimento dos posicionamentos sobre as cotas, torna-se necessário discutir alguns dos princípios de justiça que lhe são subjacentes. Contudo, para não ficarmos presos a uma discussão abstrata, vamos analisar quais visões de justiça são preponderantes no seio da população estudada e em que medida isso repercute na aceitação ou não das cotas como medidas reparatórias ou afirmativas.

Em termos metodológicos, essa pesquisa pode beneficiar-se de uma perspectiva interdisciplinar, fruto das formações acadêmicas diferentes de seus autores - um, sociólogo, com incursões pelas sociologias política e da educação, e o outro, psicólogo social, pesquisador de atitudes e representações sociais sobre o racismo e a discriminação. É a essa colaboração interdisciplinar que podemos imputar a opção pelo uso simultâneo de dados quantitativos, obtidos por questionários, com uma discussão sobre percepções de justiça no âmbito da educação. Os resultados alcançados levam-nos a pensar que a interdisciplinaridade pode incitar novas leituras e novas opções metodológicas nesse campo de investigação.

Para atingir os objetivos propostos, o trabalho está dividido em duas partes. Uma, mais conceitual, em que buscamos inserir a discussão sobre as cotas no debate teórico sobre a justiça. Outra, de caráter mais empírico, na qual apresentamos os resultados de duas pesquisas de opinião sobre as cotas, realizadas junto a estudantes universitários e pré-vestibulandos em Aracaju-SE.

Porém, desde logo deixamos claro que nosso intuito aqui é menos o de argumentar favoravelmente sobre o valor moral mais elevado de uma explicação pautada nas teorias da justiça que o de tornar mais claro um debate que se tem caracterizado por argumentos passionais, os quais tendem a demonizar ou, pelo contrário, supervalorizar as cotas. Esperamos, com isso, poder contribuir para uma discussão menos maniqueísta da questão.

\section{0 que é justiça, afinal?}

Uma questão que se pode legitimamente colocar é: o que justifica um sistema de cotas? O argumento mais utilizado é que a situação da população de origem afro-brasileira é de tal modo desigual que, por si só, mereceria um tratamento como o das cotas. Mas, a bem da verdade, isso não explica tudo. Afinal de contas, muitas são as sociedades em que as desigualdades são não apenas toleradas como também justificadas. Mas, o que torna justa, ou injusta, uma sociedade?

As teorias contemporâneas da justiça, ao buscarem definir preceitos capazes de tornar as sociedades justas, tentam responder a essa questão. ${ }^{5}$ Embora possamos dizer que são vários os critérios de justiça avançados por essas teorias, alguns dos quais divergentes, não nos parece errônea a visão de autores como Dworkin (2002) e Kymlicka (1990) segundo a qual o ponto comum entre essas é o fato de terem o igualitarismo como princípio de base.

Para John Rawls (1971), que tem o mérito de estar na origem do debate atual sobre a justiça, dois são os princípios definidores de uma sociedade justa: (a) o da igualdade fundamental entre todos os membros e (b) o de que apenas devem ser toleradas as desigualdades que resultem em benefícios para o conjunto da sociedade. Com isso, Rawls procura conciliar os princípios liberais de igualdade jurídica com uma preocupação em limitar as desigualdades sociais, priorizando em sua teoria o princípio distributivo.

Diversos autores se oporão a essa visão liberalsocial de justiça. A emergência, na segunda metade do século XX, das temáticas do direito à diferença e do multiculturalismo (Taylor, 1992; Kymlicka, 1995) colocará em evidência novas discussões e novos problemas políticos. Os movimentos identitários (de cunho étnico, de gênero, ligado às opções sexuais etc.), ao reivindicarem ações específicas dos

5 Para uma síntese dessas teorias ver Kymlicka (1990) e Vita (2000). 
governos contra a discriminação que sofrem os grupos minoritários, vão confrontar as democracias liberais com a espinhosa questão de como fazer para garantir o universalismo jurídico, pautado no princípio da igualdade de todos perante a lei, e, ao mesmo tempo, promulgar leis específicas de proteção de grupos minoritários e/ou discriminados, o que pode ser visto como um privilégio e uma não-observância do universalismo.

Desse modo, Sandel (1982) vai criticar os princípios de justiça aventados por Rawls, por expressarem uma visão individualista dos seres humanos, sem levar em consideração que a moralidade humana se constitui na vida coletiva, e que, portanto, não se pode estipular a priori que apenas o critério distributivista dos bens possa definir o que seja ou não uma sociedade justa. Para ele, uma teoria da justiça deve levar em conta o que a comunidade considera justo, uma vez que não existe uma concepção de justiça independente dos valores socialmente partilhados.

Nesse contexto, Taylor $(1989,1992)$ argumenta que a primazia dada pelas teorias distributivistas à divisão dos bens materiais na definição de uma sociedade justa escamoteia o fato de que muitas vezes as injustiças não são econômicas, mas morais. Ou seja, nessa perspectiva, é possível pensar em situações em que, malgrado certa igualdade distributiva, alguns grupos possam sentir-se oprimidos ou discriminados.

A discussão será retomada e ampliada por Honneth (2000), para quem o reconhecimento é a força motriz transformadora das sociedades modernas, devendo, pois, ser considerado o princípio definidor de uma teoria da justiça, já que ele concentra em si outros princípios, inclusive o distributivo.

Em contrapartida, a crítica feminista à teoria rawlsiana de justiça (Okin, 1989) vai insistir no fato de que as desigualdades de gênero não são mensuráveis apenas em termos de acesso aos bens materiais ou ao mercado de trabalho, pois é no seio mesmo da família que essas desigualdades se consolidam.

Assim, vai-se aos poucos se constituindo um debate bipolar sobre os critérios de justiça válidos no mundo contemporâneo: de um lado, os que priorizam a distribuição igualitária dos bens, e de outro os que priorizam o reconhecimento social que os indivíduos gozam ou não na sociedade (Honneth, 1997; Taylor, 1992; Young, 1997).

Contra essa bipolaridade dos critérios de justiça, Fraser (1997, 2000) defende que em nossa época esses critérios precisam dar conta, simultaneamente, da justiça social (ligada aos aspectos distributivistas) e da justiça simbólica (que envolve o reconhecimento das diferenças).

Essa crítica será retomada por outros autores, tais como Bauman (2003) e Rorty (1998), que irão sublinhar ainda que as demandas por reconhecimento e valorização identitária dissociadas das demandas por justiça social tendem não apenas a fixar de forma rígida os limites entre as identidades (por exemplo, gerando as guerras étnicas), mas também a manter a estrutura de poder das sociedades capitalistas avançadas, dissimulando assim a pobreza e as novas formas de exclusão.

Autores como Walzer (1983), Boltanski e Thévenot (1991) e Dubet (2006) vão argumentar que a pertinência dos critérios de justiça depende da esfera social em que se está inserido. Esse critério não pode ser o mesmo na esfera econômica ou na esfera familiar, por exemplo. Com isso, eles chamam a atenção para a existência de uma multiplicidade de critérios de justiça na vida social.

Para Habermas (1997a, 1997b) não existem critérios ad hoc e universais, exceto o de que para uma sociedade ser considerada justa é necessário que os critérios de justiça em vigor tenham sido definidos de tal forma que todo membro da sociedade possa aceitálos como razoáveis. Ou seja, ainda aqui temos a idéia de que todos são iguais e que, portanto, todos podem participar da construção dos critérios de justiça, os quais podem eventualmente colocar em suspensão a igualdade jurídica entre os membros da sociedade (como no caso das cotas), desde que isso possa ser aceito como algo justo pelos grupos não beneficiados por tais critérios. No fundo, Habermas tenta construir uma teoria eqüidistante entre as teses universalistas e contextualistas das teorias da justiça, aceitando, por 
um lado, a idéia da igualdade inata entre os homens, e por outro, a possibilidade de negociação dos critérios de justiça em uma dada sociedade, desde que eles tenham sido frutos de negociação legítima.

Esse impasse entre contextualização e universalidade dos critérios de justiça é também retomado por Chantal Mouffe (1991, 2005). Para ela, a partir de uma visão anti-essencialista, embora os princípios democráticos e igualitários tenham a hegemonia mundial, eles não devem ser vistos como expressão última da justiça. Isso significa que eles podem ser "radicalizados", e que, portanto, novos arranjos hegemônicos podem ser construídos. A questão que se coloca para os regimes democráticos é que esses novos arranjos possam garantir espaços também novos de autonomia dos sujeitos.

Esse debate teórico pode ajudar-nos a melhor compreender a polêmica sobre as cotas na sociedade brasileira atual. Isso por várias razões. Por um lado, por lembrar-nos de que a justiça é sempre uma questão de construção de certo consenso social; por outro, por colocar que esse consenso só pode ser considerado justo se ele não significar a exclusão de uma parte dos membros de uma sociedade.

A questão da construção do consenso é retomada por François Dubet (2006) ao colocar as percepções de justiça e de injustiça como centro de análise. Para ele, qualquer teoria da justiça, seja a dos filósofos, seja a dos próprios atores sociais, está baseada em três princípios: igualdade, liberdade e reconhecimento. Contudo, à diferença de outros autores, ele não vê como seja possível definir a priori qual desses princípios tem a primazia em relação aos outros, pois cada sociedade e cada indivíduo podem legitimamente erigir um desses princípios como o mais importante. Além disso, se nos posicionarmos do ponto de vista das percepções de justiça e de injustiça dos atores, o mais comum é que haja combinatórios entre os vários princípios arrolados anteriormente, inclusive no que eles têm de contraditórios. Assim, em sua pesquisa sobre o sentimento de injustiça no mundo do trabalho na França, Dubet pôde observar que um mesmo ator podia sustentar discursos contraditórios em relação ao justo e ao injusto, confor- me se posicionasse do ponto de vista da igualdade, da liberdade ou do reconhecimento.

A discussão sobre o justo e o injusto deve, pois, no âmbito das ciências humanas, sair da disputa pelos critérios atemporais de justiça para analisar quais os valores que estão subentendidos nas concepções desta e que prevalecem em uma sociedade em determinadas épocas. A definição do justo e do injusto em uma sociedade é, pois, uma questão política, que tem a ver com relações de forças e com representações sociais hegemônicas na sociedade.

Assim, podemos afirmar que é na arena dos debates sobre justiça e igualdade social que se inserem as discussões sobre as políticas de ação afirmativa para grupos minoritários.

\section{Igualdade e políticas de ação afirmativa}

As políticas de ação afirmativa (PAA) surgem do embate jurídico e político entre duas vertentes da igualdade. As revoluções burguesas ocorridas no século XVIII foram concebidas para eliminar do regime feudal privilégios com base na linhagem, herança, ou numa estrutura rígida de classes sociais, e assim acabar com as discriminações. É assim que surge a noção de "igualdade perante a lei", a qual se tornará uma pedra-chave na edificação das democracias que começam a surgir no século XIX e XX (Gomes, 2001). De acordo com essa concepção formalista da igualdade, a posição de uma pessoa na sociedade, seu tipo de emprego, sua renda, seu cônjuge, sua escolaridade etc. deveriam depender apenas das suas capacidades, sem sofrer a influência, ainda que mínima, do sexo, da cor da pele, da religião, da cultura, da origem geográfica, ou de quaisquer aspectos que estivessem fora do controle do cidadão. Esse princípio será criticado já no século XIX, quando setores da sociedade civil começam a organizar-se para lutar contra as flagrantes desigualdades sociais, como mostra a crítica marxista aos direitos burgueses (Marx, 2002).

É assim que o princípio da igualdade jurídica ou formal começa a ser questionado, a partir da constatação de que a mera garantia de direitos às pessoas des- 
favorecidas não era suficiente para que elas pudessem superar sua situação de inferiorização econômica, política e cultural. Um importante conjunto de mudanças sociais e políticas ocorridas, sobretudo, a partir dos anos de 1930, tais como a crítica ao regime nazifascista, a implantação do Estado de bem-estar social, a Declaração dos Direitos Humanos em 1948, as lutas pelos direitos civis nos Estados Unidos e o movimento feminista na década de 1960, dentre outros, cria um cenário no qual a igualdade formal destituída de igualdade real começa a ser rigorosamente questionada.

Nesse cenário, começa-se a falar em igualdade de condições, em vez de simplesmente igualdade de direitos. Esse fato cria para os sistemas políticos a necessidade de produzirem mecanismos que viabilizem a igualdade de fato, e não apenas de direito, entre as pessoas. Nesse bojo, propugna-se a necessidade de diminuir as desigualdades e aumentar as possibilidades de inclusão social pelo Estado.

Essa nova versão da igualdade, definida como "igualdade substancial", tem como objetivo permitir que as desigualdades e dessemelhanças existentes na sociedade sejam tratadas de modo específico, a fim de minimizar os abismos que existem entre as pessoas e grupos. De acordo com essa noção de igualdade, ações corretivas ou reparadoras do Estado justificam-se sempre que haja a necessidade de equacionar assimetrias entre os grupos na busca de justiça social. Isso mesmo quando essas ações pareçam discriminatórias. Estamos próximos aqui do conceito de justiça desenvolvido por John Rawls (1971), segundo o qual uma situação de desigualdade é justa quando beneficia o conjunto da sociedade.

Do mesmo modo, é no contexto do debate sobre a igualdade de oportunidades e igualdade de benefícios que Diamond e Giddens (2005) vão afirmar que a expansão das desigualdades e da pobreza em nível mundial deve fazer emergir um "novo igualitarismo", que supere a incoerência da meritocracia pura, pois, sem a distribuição da renda ou dos recursos acumulados por gerações passadas, as novas gerações podem viver apenas da especulação financeira, aumentando o caos social. Para esses autores, não sendo possível fazer a justiça social pela redistribuição, é preciso assumir metas mais modestas e realísticas e fazer uma redistribuição das oportunidades ou chances de vida que favoreça os setores mais excluídos da sociedade.

Essa forma de igualdade, quando operacionalizada em termos de políticas públicas, consiste em dar meios preferenciais aos membros de grupos desfavorecidos, em propor-lhes um tratamento diferenciado, cargos reservados nas empresas ou em instituições de ensino, vantagens fiscais, recursos complementares para escolas de determinados bairros ou regiões, entre outros.

Portanto, é no seio do princípio da igualdade substancial que as PAA surgem e se fundamentam. As ações afirmativas podem ser definidas como "políticas públicas (e privadas) voltadas à concretização do princípio constitucional da igualdade material e à neutralização dos efeitos da discriminação racial, de gênero, de idade, de origem nacional e de compleição física" (Gomes, 2003, p. 21).

\section{As políticas de ação afirmativa e as cotas}

Mas o que significam as cotas para as democracias contemporâneas e qual a sua história? No plano internacional, as PAA, dentre as quais as cotas, começam a difundir-se a partir dos anos de 1960, quando são adotadas nos Estados Unidos em resposta às mobilizações pelos direitos civis dos negros. Em 1965, uma "Ordem Executiva" é assinada por Lyndon Johnson proibindo a discriminação racial no interior das empresas. Para obrigar as empresas a aplicar essa lei, o governo norte-americano vai estabelecer, em 1968, a obrigatoriedade de cotas para negros e outras minorias étnicas na mesma proporção de sua composição na população total.

Ao longo dos anos de 1970, diversas universidades norte-americanas vão aderir a esse critério, de forma que ampliasse a representação de mulheres e de minorias étnicas entre seus estudantes. Isso, contudo, ao pôr em questão o princípio meritocrático em uma instituição que se legitima justamente em nome desse princípio, vai ser constantemente levado à apre- 
ciação da justiça. Assim, em 1978, a Corte Suprema dos Estados Unidos pronuncia-se em favor de um aluno branco que havia sido recusado na Faculdade de Medicina de Davis em conseqüência de uma política de cotas posta em prática. Na sua apreciação desse caso (caso Bakke), a Corte Suprema proíbe o uso de cotas nas universidades como critério exclusivo de seleção de candidatos oriundos de minorias, embora aceite o uso de critérios raciais na seleção. Desde então, as universidades norte-americanas não podem mais usar apenas o critério racial para garantir a diversidade étnica, pois ele deve ser obrigatoriamente mesclado com outros critérios (sociais, residenciais, de gênero etc.) (Doytcheva, 2005).

Porém, é nos anos de 1990 que as PAA de cunho étnico são mais duramente criticadas nos Estados Unidos, com a votação de leis proibindo a sua aplicação nas universidades e nas concorrências públicas em vários estados importantes (Califórnia, por plebiscito, Texas, Flórida, Washington etc.). Isso faz com que as universidades mais engajadas ponham em prática políticas preferenciais de cunho territorial para garantir a presença de habitantes de bairros carentes, majoritariamente oriundos de minorias étnicas, nos bancos universitários (idem).

No entanto, as PAA nunca estiveram restritas aos Estados Unidos (Sowell, 2004). Como refere Silva (2003), na Índia, desde a Constituição de 1948 prescrevia-se tratamento especial para os Dalits, inclusive com reserva de vagas no parlamento; na Malásia, grupos sufocados pelo poder dos chineses e indianos também tinham direito a privilégios; na antiga União Soviética havia cotas de $4 \%$ para que moradores da Sibéria tivessem acesso às universidades; na Nigéria e na Alemanha existem ações afirmativas para beneficiar mulheres; na Colômbia há benefícios para os índios, assim como no Canadá. Na África do Sul pós-apartheid os negros recebem tratamento especial do Estado.

No Brasil, desde 1990 a lei n. 8.112/90 define reserva de $20 \%$ das vagas para portadores de deficiência física em concursos públicos. Também existe reserva de vagas para as mulheres como candidatas em eleições no Brasil. A lei eleitoral n. 9.504, de 1997, estabelece um mínimo de 30\% e um máximo de 70\% de candidaturas para cada sexo (Silva, 2003). Existem, além dessas duas, várias outras formas de ações afirmativas no Brasil, que beneficiam com isenção de taxas ou com incentivos financeiros vários grupos sociais, a exemplo de professores da rede pública estadual que, em vários estados do Brasil, tiveram seu acesso e sua permanência nas universidades públicas facilitados por políticas educacionais. No entanto, nenhuma dessas ações causa estardalhaço ou polêmicas sociais, pois não envolvem um tabu histórico da sociedade brasileira: a cor da pele (idem).

Em que pese a polêmica que reveste esse tema, a criação de cotas para negros fez surgir no Brasil, pela primeira vez, um constante e intenso debate sobre preconceito, discriminação e identidade étnicas. Esse debate tem construído e polarizado atitudes favoráveis ou contrárias às cotas que configuram redes complexas de percepção e representação das relações racializadas no Brasil bem como da idéia de justiça que permeia essas relações.

O debate sobre as cotas traz no seu bojo a discussão sobre a desigualdade no Brasil, desigualdade entre brancos e não-brancos, entre ricos e pobres etc. O que parece estar ocorrendo nas últimas décadas em nosso país é uma mudança na percepção das desigualdades que devem ser toleradas ou não. Pensamos que o reconhecimento da existência de desigualdades ligadas à idéia de raça faz parte dessa transformação.

\section{As percepções sobre as cotas para negros nas universidades públicas}

Com o objetivo de analisar a relação entre as percepções de justiça ou de injustiça social com as opiniões sobre as cotas, realizamos dois estudos junto a grupos que têm uma implicação direta com essa questão: pré-vestibulandos e estudantes de uma universidade pública. ${ }^{6}$ Nesses estudos examinamos tam-

${ }^{6}$ Essa é uma particularidade da presente pesquisa em relação às pesquisas de opinião realizadas no âmbito nacional com o 
bém as relações entre estrato social, identidade étnica, percepções de justiça social e as atitudes em relação às cotas para minorias no Brasil.

\section{Estudo 1}

\section{M étodo}

\section{Participantes}

Participaram 122 estudantes de dois cursos preparatórios para o vestibular em Aracaju, sendo 61 estudantes de um pré-vestibular público promovido pela Secretaria de Educação do Estado, e outros 61 de um pré-vestibular privado. No que concerne à idade, à renda familiar e ao gênero, notamos que os estudantes do curso privado são em média mais jovens que os do curso público $(M=19,7$ vs. $M=21,3)$. O desvio padrão das idades indica também que há uma maior dispersão de idades entre os estudantes do curso público. Com relação à renda familiar, como era de se esperar, existem diferenças entre os dois grupos. Entre os estudantes do curso público, $82 \%$ (50 deles) possuem renda familiar compreendida entre um e cinco salários mínimos, ao passo que nos estudantes do curso privado apenas 36\% (22 indivíduos) possuem renda familiar igual ou inferior a cinco salários mínimos. Houve ainda 11 estudantes da rede privada que não declararam renda. Já na escola pública, todos informaram a renda. Em relação à autoclassificação da cor da pele, ${ }^{7}$ verificamos que mais estudantes se

conjunto da população. Priorizamos aqui discutir como as cotas são percebidas entre os estudantes que se preparam para o vestibular ou já entraram nas universidades, população diretamente implicada pelas cotas o que nos leva a uma perspectiva em que os critérios de justiça não são discutidos de forma independente de possíveis interesses específicos dos grupos sociais.

${ }^{7}$ Os participantes do estudo deveriam escolher entre "negros", "pardos", "brancos", "amarelos" ou indígenas", o rótulo que melhor definia a sua cor. Considerando, simultaneamente, a quase inexistência de respostas em termos de "amarelos" ou "indígenas" e os objetivos da pesquisa, agrupamos os "negros" com autodefinem como negros na escola pública (83\%) do que na privada (70\%); o inverso observa-se para a cor branca ( $17 \%$ na pública e $30 \%$ na privada). As outras classificações de cor (índios e amarelos) foram residuais, por isso não as consideramos nessas análises. Com relação ao sexo, nas duas escolas, mais de $70 \%$ dos entrevistados são do sexo feminino.

\section{Procedimentos e instrumentos}

Os estudantes foram contatados em sala de aula e responderam um questionário sobre atitudes e identidades sociais. O questionário era composto de perguntas sobre identidade étnica ou de cor (e.g., como se percebe, se sente satisfeito com a cor que possui, sente orgulho), comparações sociais e percepções de justiça social (e.g., como avalia a situação econômica dos negros no Brasil em relação aos brancos, acha essa situação justa ou injusta, acha possível que essa situação se altere) e atitudes diante das diferentes modalidades de cotas (e.g., cotas para mulheres, para deficientes físicos, para negros e pardos, para estudantes da rede pública etc.).

É pertinente salientar que dentre os pré-vestibulandos apenas $25 \%$ se autodefiniram como brancos, sendo que no pré-vestibular público negros e pardos, juntos, totalizaram $84 \%$.

\section{Resultados e discussão}

\section{Atitudes e opiniões em relação às cotas}

Primeiramente analisamos as atitudes dos estudantes em relação a algumas modalidades de cotas de acesso. Os resultados indicam que, no geral, os pré-

os "pardos". Essa classificação é ligeiramente diferente daquela usada pelo Instituto Brasileiro de Geografia e Estatística (IBGE), que emprega os termos preto, pardo e negro, sendo este último a soma de pretos e pardos. Contudo, dadas as características do linguajar corrente em Sergipe, preferimos manter o termo negro para nos referirmos às pessoas de pele negra, evitando assim confusões de interpretação durante a aplicação dos questionários. 
vestibulandos são contra as cotas, aceitando apenas cotas para deficientes físicos em concursos públicos. Com relação às cotas de acesso para negros e pardos nas universidades públicas, apenas 18,9\% dos prévestibulandos foram favoráveis (ver Tabela 1).

Tabela 1

Atitudes dos pré-vestibulandos em relação às cotas (dados em percentagens)

\begin{tabular}{|l|c|c|c|c|}
\hline \multirow{2}{*}{ Cotas para } & \multicolumn{3}{|c|}{ Atitude } & Total \\
\cline { 2 - 5 } & Favorável & Contrário & S/posição* & \\
\hline $\begin{array}{l}\text { Deficientes físicos em } \\
\text { concursos públicos }\end{array}$ & 66,0 & 34,0 & - & 100,0 \\
\hline $\begin{array}{l}\text { Mulheres em cargos } \\
\text { políticos (e.g., } \\
\text { vereadoras, } \\
\text { deputadas, senadoras) }\end{array}$ & 32,5 & 67,5 & - & 100,0 \\
\hline $\begin{array}{l}\text { Trabalhadores negros } \\
\text { em empresas privadas }\end{array}$ & 38,0 & 62,0 & - & 100,0 \\
\hline $\begin{array}{l}\text { Estudantes negros e } \\
\text { pardos em } \\
\text { universidades públicas }\end{array}$ & 18,9 & 65,6 & 15,5 & 100,0 \\
\hline
\end{tabular}

* Para essas três primeiras perguntas só havia as opções "favorável" ou "desfavorável".

Mas será que as atitudes em relação às cotas dos estudantes se diferenciam em função do tipo de escola? Para respondermos a essa pergunta realizamos testes qui-quadrado, ${ }^{8}$ tomando a escola (pública ou privada) como eixo de análise. Os resultados indicam que existe uma diferença significativa entre os prévestibulandos da rede pública e da rede privada $\left(\mathrm{c}^{2}=\right.$ $22,34, \mathrm{GL}=2, p<0,0001)$. Como podemos ver na Tabela 2, menos da metade dos pré-vestibulandos da escola pública são contrários às cotas, ao passo que entre os da escola privada esse percentual sobe para mais de $85 \%$.

${ }^{8} \mathrm{O}$ teste qui-quadrado (Chi-Square) permite verificar a relação entre a frequiência de resposta observada numa determinada amostra com a freqüência esperada ou hipotetizada. Esse teste é representado pelo símbolo $\mathrm{c}^{2}$. No teste qui-quadrado, o "GL" significa os "graus de liberdade" considerados na análise. Os GLs são uma hipótese de variação estatística referente ao número de valores que se podem dever ao acaso dentro de uma distribuição.
Tabela 2

Atitudes dos pré-vestibulandos em relação às cotas para estudantes negros e pardos nas universidades públicas em função do tipo de escola (dados em percentagens)

\begin{tabular}{|l|c|c|c|c|}
\hline \multirow{2}{*}{ Tipo de pré-vestibular } & \multicolumn{3}{|c|}{ Atitude } & \multirow{2}{*}{ Total } \\
\cline { 2 - 4 } & Favorável & Contrário & S/posiçãon & \\
\hline Público & 32,8 & 45,9 & 21,3 & 100,0 \\
\hline Privado & 4,9 & 85,2 & 9,9 & 100,0 \\
\hline Total & 18,9 & 65,6 & 15,5 & 100,0 \\
\hline
\end{tabular}

Indagamos ainda se estudantes beneficiados pelas cotas são menos merecedores da vaga, se teriam desempenho pior que os não-"cotistas" e se seriam discriminados na universidade. Na Tabela 3 podemos ver que existem diferenças significativas entre os estudantes da escola pública e da privada nas duas questões. A maioria dos pré-vestibulandos da rede privada considera o cotista menos merecedor da vaga, enquanto a maioria dos pré-vestibulandos da escola pública não pensa assim $\left(c^{2}=16,94, \mathrm{GL}=2\right.$, $p<0,0001)$. Embora a maioria dos estudantes acredite que os cotistas serão discriminados na universidade, é maior o percentual de concordância com essa afirmação entre os pré-vestibulandos da escola privada do que entre os da pública $\left(c^{2}=7,99, \mathrm{GL}=2\right.$, $p<0,005)$.

Tabela 3

Percepções sobre os cotistas em função do tipo de escola (dados em percentagens)

\begin{tabular}{|c|c|c|c|c|c|c|}
\hline \multirow[t]{3}{*}{ Item } & \multicolumn{6}{|c|}{ Tipo de escola } \\
\hline & \multicolumn{3}{|c|}{ Pública } & \multicolumn{3}{|c|}{ Privada } \\
\hline & Sim & Não & Não sei & Sim & Não & Não sei \\
\hline $\begin{array}{l}\text { Um estudante } \\
\text { negro ou pardo } \\
\text { que ingressa na } \\
\text { universidade pelo } \\
\text { sistema de cotas é } \\
\text { menos merecedor } \\
\text { da vaga do que um } \\
\text { não-cotista? }\end{array}$ & 24,6 & 55,7 & 19,7 & 60,7 & 32,8 & 6,5 \\
\hline $\begin{array}{l}\text { Os estudantes } \\
\text { beneficiados pelas } \\
\text { cotas serão } \\
\text { discriminados na } \\
\text { universidade? }\end{array}$ & 62,0 & 38,0 & - & 85,0 & 15,0 & - \\
\hline
\end{tabular}


Mas qual seria o papel da cor da pele na definição dessas atitudes? Não existe influência significativa da cor da pele sobre as atitudes em relação às cotas de acesso para estudantes negros e pardos nas universidades públicas. Os estudantes que se autodefinem como brancos e os que se autodefinem como negros ou pardos são, em sua maioria, contrários às $\operatorname{cotas}\left(76 \%\right.$ e $60 \%$, respectivamente) $\left(c^{2}=3,01, \mathrm{GL}=\right.$ $2, n . s$.$) .$

A fim de termos um indicador de identidade étnica ou de cor, perguntamos também em que medida o estudante sentia orgulho da sua cor de pele, numa escala cuja resposta poderia variar de 1 (nada orgulhoso) a 5 (totalmente orgulhoso). Verificamos que tanto os negros e pardos $(M=4,41)$ quanto os bran$\cos (M=4,12)$ sentem orgulho da sua cor, sem diferenciação estatística.

Também não houve diferenças entre os brancos e não-brancos no que concerne à percepção de mérito nos cotistas $\left(c^{2}=2,69, \mathrm{GL}=2\right.$, n.s. $)$, à avaliação do seu desempenho $\left(\mathrm{c}^{2}=4,18, \mathrm{GL}=3\right.$, n.s. $)$ e à crença de que os cotistas serão discriminados nas universidades $\left(\mathrm{c}^{2}=0,86, \mathrm{GL}=1, n . s\right.$. $)$. Os cotistas foram avaliados como merecedores das vagas para $49 \%$ dos pardos e negros e $32 \%$ dos brancos; $3 / 4$ dos negros e pardos e $65 \%$ dos brancos consideraram que os cotistas serão discriminados na universidade.

\section{Percepções de justiça social e estabilidade do sistema}

A fim de entendermos as visões de justiça ou injustiça social e as percepções de estabilidade do sistema, solicitamos aos estudantes que pensassem na situação dos negros e dos brancos no Brasil e fizessem comparações. Verificamos, pelas análises de variância, ${ }^{9}$ que não existe uma diferença significativa entre as avaliações dos estudantes da escola pública e

${ }^{9}$ Conhecido como "anova", esse teste estatístico, representado pelo símbolo $F$, de Fisher, seu criador, permite calcular se a variação entre duas ou mais médias é significativamente diferente. da escola privada, seja no que tange à situação dos negros em relação aos brancos, $F(1,108)<1$, n.s., seja ainda no que se refere à percepção de justiça desta situação, $F(1,113)<1, n$.s. De modo que tanto os pré-vestibulandos da escola pública quanto os da particular concordam que a situação dos negros é pior do que a dos brancos (médias próximas de 4) e que essa é uma situação injusta (médias próximas de 3 ).

Tabela 4

Percepções de justiça social em função do tipo de escola (dados em médias)

\begin{tabular}{|l|c|c|c|c|}
\hline \multirow{2}{*}{ Questão } & \multicolumn{3}{|c|}{ Tipo de escola } \\
\cline { 2 - 5 } & \multicolumn{2}{|c|}{ Pública } & \multicolumn{2}{c|}{ Privada } \\
\cline { 2 - 5 } & Média & $\begin{array}{l}\text { Desvio } \\
\text { Padrão }\end{array}$ & Média & $\begin{array}{l}\text { Desvio } \\
\text { Padrão }\end{array}$ \\
\hline $\begin{array}{l}\text { Como avalia a situação } \\
\text { econômica dos negros no } \\
\begin{array}{l}\text { Brasil em relação aos } \\
\text { brancos? * }\end{array}\end{array}$ & 4,04 & 0,84 & 4,02 & 0,79 \\
\hline $\begin{array}{l}\text { Você acabou de avaliar a } \\
\text { situação dos negros em } \\
\text { relação aos brancos. O que } \\
\text { acha dessa situação? ** }\end{array}$ & 3,29 & 0,75 & 3,27 & 0,77 \\
\hline
\end{tabular}

* A escala variava de 1 (muito melhor), 2 (melhor), 3 (igual), 4 (pior) e 5 (muito pior).

** A escala variava de 1 (totalmente justa), 2 (justa), 3 (injusta) e 4 (totalmente injusta).

Quando indagamos se a situação econômica dos negros em relação aos brancos pode alterar-se, verificamos que, independentemente do tipo de escola, ${ }^{10} \mathrm{a}$ maioria dos estudantes responde que "sim" (74\%) contra apenas $26 \%$ que dizem "não".

Mas não será a cor da pele um elemento fundamental na definição das percepções de justiça social?

A cor da pele dos participantes não interferiu nas suas percepções de justiça social. Brancos e não-brancos consideram que os negros estão em pior situação econômica $(M=3,96$ e $M=4,03), F(1,96)<1, n . s$. E ambos os grupos, também de modo indiferenciado, consideram essa situação injusta, $F(1,100)<1, n . s$; embora quase todos considerem possível que essa situação se altere ( $71 \%$ dos negros e pardos e $83 \%$ dos brancos).

$$
{ }^{10} \mathrm{c}^{2}=0,56, \mathrm{GL}=1, \text { n.s. }
$$


Todas essas análises permitem-nos perceber um impacto parcializado de determinados indicadores nas atitudes dos estudantes sobre as cotas. Qual será, no entanto, o impacto global desses indicadores?

\section{0 impacto das percepções de justiça social e da posição na estrutura social nas atitudes em relação às cotas}

Quando realizamos uma análise de correspondências múltiplas ${ }^{11}$ a fim de visualizarmos a relação de todos os nossos indicadores com as atitudes em relação às cotas, encontramos uma grande oposição que estrutura os campos semânticos e que separa o pré-vestibular público do pré-vestibular privado. $\mathrm{O}$ pré-vestibular público forma um campo representacional no qual se encontra a maioria dos favoráveis às cotas, que possuem renda familiar entre um e cinco salários mínimos, e daqueles que sentem orgulho da sua cor. No campo oposto estão os pré-vestibulandos da rede privada, mais contrários às cotas, que possuem renda familiar mais elevada e são ainda os que mais se autodefinem como brancos. Os que se definem como negros ou como pardos ocupam um quadrante no qual se encontram os que ainda não formaram atitude sobre cotas, que acreditam que a situação econômica dos negros em relação aos brancos é igual ou melhor, justa, e não se altera. Finalmente, no quadrante oposto estão os que afirmam que a situação dos negros em relação aos brancos é pior, mas pode alterar-se. Nesse espaço estão ainda os que não sentem orgulho da sua cor (ver Figura 1).

${ }^{11}$ Tipo de técnica de análise de dados que permite estudar a relação entre mais de duas variáveis nominais ou categóricas, pela organização da informação de modo hierarquizado, com a criação de agrupamentos de variáveis por semelhanças de freqüência de resposta.

\section{Figura 1}

Análise de correspondências múltiplas (Homals) dos indicadores de posição objetiva e subjetiva no sistema e das atitudes em relação às cotas dos pré-vestibulandos $(\mathrm{n}=122)$ *

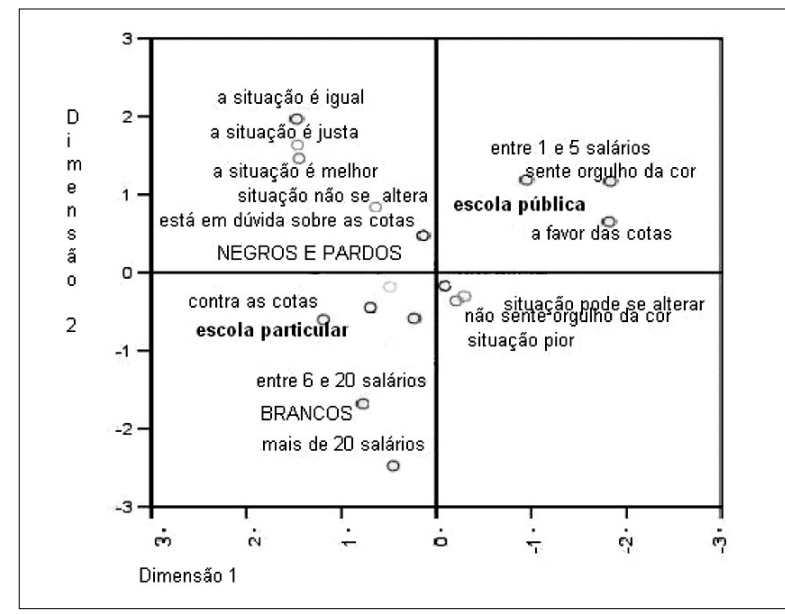

* O Eigenvalue (indicador da contribuição de cada dimensão na explicação do fenômeno) da Dimensão 1 foi de 0,26, e o da Dimensão 2 foi de 0,25 . Esses valores indicam que o vetor de interpretação mais apropriado para os dados é aquele que separa os quatro quadrantes.

\section{Estudo $2^{12}$}

No Estudo 1 vimos como estudantes que se estão preparando para entrar na universidade reagem à política de cotas. Cabe agora indagar como os estudantes que já estão numa universidade pública se posicionam acerca das cotas de acesso para negros e pardos. Nesse sentido, realizamos um segundo estudo com o objetivo de analisar como estudantes de todos os cursos da Universidade Federal de Sergipe (UFS) (única universidade pública do estado) se posicionam em relação às cotas e qual o impacto das percepções de justiça social e dos indicadores de posicionamento social e econômico nessas atitudes.

\footnotetext{
${ }^{12}$ Esta pesquisa teve a colaboração fundamental de estudan-
} tes dos cursos de ciências sociais e psicologia da UFS, que realizaram as aplicações dos questionários e colaboraram na tabulação dos dados. 


\section{M étodo}

\section{Participantes}

Participaram 1.154 estudantes de todas as áreas de concentração da UFS. Desses, 28,5\% eram do Centro de Ciências Exatas e Tecnológicas $(n=329), 30 \%$ do Centro de Educação e Ciências Humanas $(n=346)$, $20 \%$ do Centro de Ciências Biológicas e da Saúde (n =231) e 21,5\% do Centro de Ciências Sociais Aplicadas $(\mathrm{n}=248)$. Essa amostra é representativa da população de estudantes matriculados $(\mathrm{n}=9.895)$ no período do segundo semestre de 2004, com uma margem de erro inferior a 2 pontos percentuais na universidade como um todo. A idade dos estudantes variou de 17 a $69 \operatorname{anos}(M=22,6, D P=4,64)$. Com relação à renda familiar, a maior parte dos estudantes possui renda compreendida entre um e cinco salários mínimos (33,9\%); outros $26,8 \%$ têm renda entre seis e dez salários mínimos, $21 \%$ entre 11 e 20 salários mínimos, e apenas 14,3 possuem renda familiar superior a 21 salários mínimos. Houve ainda $4 \%$ que não informaram a renda.

Em termos da autodefinição da cor da pele, verificamos que $8,6 \%$ se definem como negros, $46,6 \%$ como pardos, $29,9 \%$ como brancos, $8,2 \%$ como amarelos, $1,2 \%$ como indígenas, e 5,5\% escolhem outra cor para se autodefinir. As mulheres foram maioria no grupo pesquisado (55\%), estudantes que trabalham somaram $41 \%$, e $15 \%$ estudam em cursos noturnos.

\section{Procedimentos e instrumentos}

Os procedimentos de aplicação foram idênticos aos do Estudo 1. O instrumento utilizado resultou de uma ampliação do instrumento do estudo anterior.

\section{Resultados e discussão}

\section{Atitudes e opiniões em relação às cotas}

Assim como fizemos no primeiro estudo, indagamos aos estudantes como eles se posicionam em relação a algumas modalidades de cotas de acesso das minorias. Neste estudo, acrescentamos uma pergunta sobre cotas de acesso às universidades públicas para estudantes de escolas públicas. Os resultados indicam uma atitude muito contrária a todos os tipos de cotas, com a única exceção daquelas que beneficiam deficientes físicos em concursos públicos, ainda que, mesmo para essas, pouco mais da metade da amostra seja favorável. Chama especial atenção a rejeição às cotas para estudantes negros e pardos nas universidades públicas, expressa por quase $80 \%$ dos inquiridos. É de notar-se que as cotas para estudantes da rede pública de ensino apresentam rejeição bem mais baixa (55,8\% são contrários) (ver Tabela 5).

Tabela 5

Atitudes dos estudantes universitários em relação às cotas (dados em percentagens)

\begin{tabular}{|l|c|c|c|c|}
\hline \multirow{2}{*}{ Cotas para } & \multicolumn{3}{|c|}{ Atitude } & \multirow{2}{*}{ Total } \\
\cline { 2 - 5 } & Favorável & Contrário & S/posição & \\
\hline $\begin{array}{l}\text { Deficientes físicos em } \\
\text { concursos públicos }\end{array}$ & 52,0 & 33,0 & 15,0 & 100,0 \\
\hline $\begin{array}{l}\text { Mulheres em cargos } \\
\text { políticos (e.g., } \\
\text { vereadoras, } \\
\text { deputadas, senadoras) }\end{array}$ & 14,5 & 74,3 & 11,2 & 100,0 \\
\hline $\begin{array}{l}\text { Trabalhadores negros } \\
\text { em empresas privadas }\end{array}$ & 15,5 & 68,9 & 15,6 & 100,0 \\
\hline $\begin{array}{l}\text { Estudantes de escolas } \\
\text { públicas nas universi- } \\
\text { dades públicas }\end{array}$ & 34,4 & 55,8 & 9,8 & 100,0 \\
\hline $\begin{array}{l}\text { Estudantes negros e } \\
\text { pardos em } \\
\text { universidades públicas }\end{array}$ & 11,7 & 79,5 & 8,8 & 100,0 \\
\hline
\end{tabular}

Quando comparamos os dados dos estudantes pré-vestibulandos com os dados dos estudantes universitários, podemos perceber que, não obstante o fato de o impacto das cotas em termos de vagas ser menos ameaçador para um estudante que já ingressou na universidade, de um modo geral os estudantes universitários são mais contrários a todas as formas de cotas (exceto as cotas para deficientes físicos) do que os pré-vestibulandos. E, mais do que isso, mesmo quando comparamos apenas os estudantes do pré-vestibular privado com os da UFS nas suas atitudes em relação às cotas para negros e pardos nas universidades, vemos que existe uma diferença mínima no per- 
centual dos "contrários": $85 \%$ no caso do pré-vestibular e 79,5\% no caso da UFS.

Mas será que existe um efeito da cor da pele dos universitários nas suas atitudes em relação às cotas?

Para respondermos a essa pergunta, realizamos cruzamentos tomando a cor da pele como eixo de análise. Os resultados indicam que, diferentemente do primeiro estudo, existe um efeito significativo da cor da pele sobre as atitudes em relação às cotas $\left(\mathrm{c}^{2}=15,39\right.$, $\mathrm{GL}=4, p<0,01)$. Como podemos ver na Tabela 6 , os mais favoráveis às cotas são os negros e pardos e os de outras cores. Os de outras cores também são os que estão mais em dúvida acerca desse tema.

Tabela 6

A titudes dos pré-vestibulandos em relação às cotas para estudantes negros e pardos nas universidades públicas em função da cor da pele (dados em percentagens)

\begin{tabular}{|l|c|c|c|c|}
\hline \multirow{2}{*}{ Cor da pele } & \multicolumn{3}{|c|}{ Atitude } & Total \\
\cline { 2 - 5 } & Favorável & Contrário & S/posição & \\
\hline Brancos & 7,9 & 83,9 & 8,2 & 100,0 \\
\hline Negros e pardos & 14,0 & 78,6 & 7,4 & 100,0 \\
\hline $\begin{array}{l}\text { Outras cores (indígenas, } \\
\text { amarelos e outras) }\end{array}$ & 11,2 & 74,7 & 14,1 & 100,0 \\
\hline
\end{tabular}

Considerando o nosso indicador de identidade de cor, constatamos nesse segundo estudo um efeito significativo da cor da pele, $F(2,953)=44,54, p<$ 0,001 . Verifica-se que os negros e pardos $(M=4,41)$ sentem mais orgulho da sua cor do que os brancos $(M$ $=3,68)$ e do que os de outras cores $(M=4,04) .{ }^{13}$

Assim como no Estudo 1, indagamos aos estudantes se os beneficiados pelas cotas são menos merecedores da vaga, se teriam um desempenho pior que os não-cotistas e se seriam discriminados na universidade. Nesse segundo estudo, acrescentamos duas outras perguntas: "Qual será o impacto das cotas na qualidade de ensino?" e "Se você pudesse, teria optado pelo sistema de cotas para entrar na universidade?".

\footnotetext{
${ }^{13}$ Teste Post Hoc Scheffé, $\mathrm{p}<0,05$.
}

Em relação à avaliação do impacto das cotas na qualidade de ensino das universidades públicas, observamos que a maioria dos pesquisados afirma que a qualidade não se alterará $(42,1 \%)$, outros $28 \%$ afirmam que a qualidade vai cair e $28,7 \%$ não sabem avaliar. Houve ainda 1,2\% de respostas de que a qualidade irá aumentar. Sobre o desempenho do cotista em relação aos não-cotistas, verificamos que mais de $40 \%$ afirmam que o desempenho será inferior $(40,3 \%)$, $24,2 \%$ dizem que será igual e 34,2\% não sabem avaliar. Outros $1,3 \%$ dizem que o cotista terá um desempenho superior ao não-cotista.

Na Tabela 7 podemos ver que, de um modo geral, os universitários acreditam que os cotistas serão discriminados nas universidades e que eles são menos merecedores da vaga do que os não-cotistas. Talvez por essas avaliações, dois terços dos pesquisados afirmam que não optariam pelas cotas de acesso às universidade públicas, mesmo se pudessem.

Tabela 7

Percepções sobre os cotistas (dados em percentagens)

\begin{tabular}{|l|c|c|c|}
\hline Questões & Sim & Não & $\begin{array}{c}\text { Não sei } \\
\text { responder }\end{array}$ \\
\hline $\begin{array}{l}\text { Um estudante negro ou } \\
\text { pardo que ingressa na } \\
\text { universidade pelo sistema } \\
\text { de cotas é menos merece- } \\
\text { dor da vaga do que um } \\
\text { não-cotista? }\end{array}$ & 44,5 & 35,8 & 19,7 \\
\hline $\begin{array}{l}\text { Os estudantes beneficiados } \\
\text { pelas cotas são ou serão } \\
\text { discriminados na universi- } \\
\text { dade? }\end{array}$ & 74,4 & 25,6 & - \\
\hline $\begin{array}{l}\text { Se você pudesse, teria } \\
\text { optado pelo sistema de } \\
\text { cotas para ingressar na } \\
\text { universidade? }\end{array}$ & 34,0 & 66,0 & - \\
\hline
\end{tabular}

Novamente avaliamos por testes qui-quadrado o efeito da cor da pele sobre essas atitudes e opiniões. Os resultados indicam que, assim como no Estudo 1, brancos, pardos e negros não se diferenciaram no que concerne à percepção de mérito dos cotistas $\left(\mathrm{c}^{2}=7,50\right.$, $\mathrm{GL}=4$, n.s. $)$, à avaliação do seu desempenho $\left(\mathrm{c}^{2}=\right.$ $9,70, \mathrm{GL}=6$, n.s. $)$, à crença de que os cotistas serão 
discriminados nas universidades $\left(\mathrm{c}^{2}=1,16, \mathrm{GL}=2\right.$, n.s.), à avaliação do impacto das cotas nas universidades públicas ( $\mathrm{c}^{2}=4,98, \mathrm{GL}=6$, n.s. $)$ e à decisão de optar ou não pelas cotas ( $\mathrm{c}^{2}=1,66, \mathrm{GL}=4$, n.s. $)$.

Chama novamente atenção o fato de que na universidade a percepção dos cotistas é mais negativa do que nos pré-vestibulares, sobretudo o público. Merece destaque o fato de a cor da pele não ter interferido de modo significativo nessas avaliações.

\section{Percepções de justiça social e estabilidade do sistema}

Com o objetivo de entendermos o papel das pertenças étnicas nas percepções de justiça social, analisamos o efeito da cor da pele sobre as avaliações que os estudantes fazem da situação dos negros e dos brancos no Brasil. Verificamos que existe um impacto da cor da pele sobre a percepção da situação econômica dos negros em relação aos brancos, $F(2,1013)=3,65$, $p<0,05$. Embora, de um modo geral, todos considerem a situação econômica dos negros pior do que a dos brancos (todas as médias são superiores a 4,0), os estudantes que se autodefinem como negros e pardos consideram a situação econômica dos negros em relação aos brancos pior do que aqueles estudantes que se definem como brancos consideram. Em relação à justiça ou legitimidade de tal situação, não houve um efeito da cor da pele, $F(2,994)=1,61, p>0,10$; de modo global, as médias indicam que a maioria considerou essa situação como injusta (ver Tabela 8).

Quando questionados se a situação econômica dos negros em relação aos brancos poderia alterar-se, os universitários, independentemente da cor da pele $\left(\mathrm{c}^{2}=2,73\right.$, $\mathrm{GL}=2, n . s$.$) , respondem "sim" (80,3\%), contra apenas$ $19,7 \%$ que afirmam não acreditarem que se altere.

\section{O impacto das percepções de justiça social e da posição na estrutura social nas atitudes em relação às cotas}

A fim de termos uma visão mais integradora do impacto das variáveis estudadas sobre as atitudes em
Tabela 8

Percepções de justiça social em função da cor da pele (dados em médias)

\begin{tabular}{|c|c|c|c|c|}
\hline \multirow[t]{2}{*}{ Percepção de justiça social } & \multicolumn{4}{|c|}{ Cor da pele } \\
\hline & Brancos & $\begin{array}{l}\text { Negros } \\
\text { e Pardos }\end{array}$ & $\begin{array}{l}\text { Outras } \\
\text { Cores }\end{array}$ & Total \\
\hline $\begin{array}{l}\text { Como avalia a situação } \\
\text { econômica dos negros no } \\
\text { Brasil em relação aos } \\
\text { brancos?* }\end{array}$ & $\begin{array}{l}4,09 a \\
(0,73)\end{array}$ & $\begin{array}{l}4,22 b \\
(0,69)\end{array}$ & $\begin{array}{l}4,12_{a b} \\
(0,63)\end{array}$ & 4,17 \\
\hline $\begin{array}{l}\text { Você acabou de avaliar a } \\
\text { situação dos negros em } \\
\text { relação aos brancos. O que } \\
\text { acha dessa situação? } * *\end{array}$ & $\begin{array}{c}3,42 \\
(0,70)\end{array}$ & $\begin{array}{c}3,42 \\
(0,63)\end{array}$ & $\begin{array}{c}3,29 \\
(0,75)\end{array}$ & 3,40 \\
\hline
\end{tabular}

* A escala variava de 1 (muito melhor), 2 (melhor), 3 (igual), 4 (pior) e 5 (muito pior).

** A escala variava de 1 (totalmente justa), 2 (justa), 3 (injusta) e 4 (totalmente injusta).

Nota: Médias com letras diferentes são significativamente diferentes (Scheffé $p<0,05)$.

Figura 2

Análise de correspondências múltiplas (Homals) dos indicadores de posição objetiva e subjetiva no sistema e das atitudes em relação às cotas dos universitários $(\mathrm{n}=1154)^{*}$

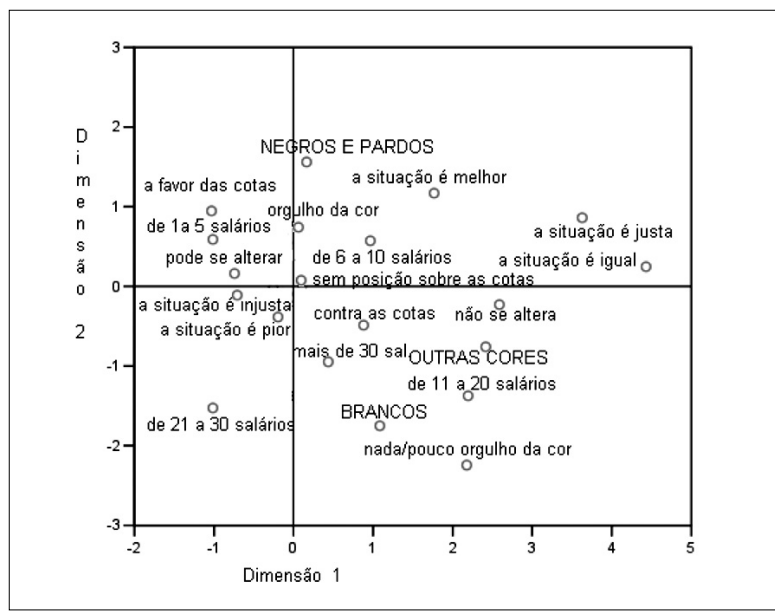

* Os Eigenvalues da Dimensão 1 e da Dimensão 2 foram, respectivamente, 0,25 e 0,20. Esses valores indicam que uma direção de interpretação adequada é a que opõe os eixos verticais.

relação às cotas dos universitários, realizamos uma análise de correspondências múltiplas com todos os indicadores pesquisados. Na Figura 2 podemos ver que a favorabilidade às cotas se associa com uma renda familiar mais baixa, com a crença de que a situação de assimetria econômica entre brancos e negros pode 
ser alterada, com o orgulho da cor da pele e com a pertença ao grupo dos negros e pardos. No campo semântico oposto estão os contrários às cotas. São, sobretudo, os que pertencem ao grupo dos brancos e a outras cores, com renda familiar mais elevada, que não acreditam que a situação econômica dos negros se altere, e que sentem nenhum ou pouco orgulho da cor.

\section{Considerações finais}

Os resultados desta pesquisa interpelam-nos sobre o significado das cotas no cenário brasileiro e, mais especificamente, sergipano. Como vimos, a maioria dos entrevistados reconhece que os negros têm dificuldades de acesso às universidades, e que isso é injusto, pois gera dificuldades de integração para os negros em outras esferas sociais. Contudo, as cotas não são aceitas pela maioria como as medidas mais indicadas. A maioria prefere as medidas universalistas (pautadas no mérito individual) às medidas afirmativas.

Não temos elementos empíricos que possam nos informar sobre se esses resultados são próprios ao estado de Sergipe ou se podem ser generalizados para outros estados. Como vimos anteriormente, as pesquisas de opinião de âmbito nacional publicadas sobre a temática mostram uma tendência a uma maior aceitação das cotas na opinião pública; mas, além do fato de essas pesquisas não terem focado a comunidade universitária, elas próprias mostram que há elementos contraditórios nas respostas dos questionários, demonstrando pouca informação sobre o tema. ${ }^{14}$

${ }^{14} \mathrm{Na}$ pesquisa realizada pelo Datafolha, citada anteriormente, o próprio coordenador da pesquisa esclarece que apenas um entre dez dos entrevistados dizia-se esclarecido sobre o tema e que, ao mesmo tempo em que $65 \%$ deles se declaravam favoráveis às cotas, $78 \%$ diziam-se favoráveis a que os critérios de mérito pessoal fossem os únicos meios de avaliação, e um número ainda maior (87\%) era favorável às cotas para alunos carentes, independentemente da cor. Essas aparentes contradições mostrariam, segundo os responsáveis pela pesquisa, que "os brasileiros desejam uma
Podemos, contudo, aventar a hipótese de que a realidade regional influencia a percepção do debate sobre as cotas. A presença de movimentos negros organizados e politicamente ativos, ${ }^{15}$ a forma como a questão racial é regionalmente debatida, ou mesmo a composição da população em termos de cor da pele podem estar informando debates regionalmente diferenciados no país. De uma forma geral, é claro que, se as cotas emergem como políticas públicas nos anos de 2000, é porque, em certo sentido, a identidade nacional está em transformação, ${ }^{16}$ como mostra a rediscussão sobre o preconceito e a discriminação racial em esferas públicas, ampliada a partir do final dos anos de 1970. Contudo, as cotas vão além das denúncias contra o preconceito racial; elas implicam também uma instrumentalização de identidades racializadas na cena pública. ${ }^{17}$ Além disso, as cotas desestabilizariam também algumas identidades regionais no país.

Tentamos mostrar alhures (Neves, 2001) como a questão negra no Brasil ganha cores regionais distin-

maior inclusão dos mais pobres, sejam negros ou não, nas universidades, concordam inicialmente com a proposta das cotas, mas valorizam também o mérito do desempenho escolar" (Folha de S.Paulo, 23 jul. 2006, p. C4). De todo modo, essa pesquisa demonstrou ainda que as resistências às cotas aumentam com o nível educacional e de renda da população, pois $55 \%$ dos que tinham nível superior e $57 \%$ dos que percebiam renda acima de dez salários mínimos eram contrários a elas. $\mathrm{O}$ que parece sinalizar tendência semelhante à observada em nossa pesquisa, malgrado o fato de elas terem sido feitas com critérios diferentes de amostragem e em épocas diferentes.

15 Neves (2000, 2005a) mostrou que, no caso sergipano, o movimento negro tem ensejado pouca participação social em suas bandeiras de luta.

${ }^{16}$ Para uma discussão dessa transformação identitária em termos políticos ver Neves (1997). Com relação às mudanças na percepção da questão negra nas últimas décadas ver Neves (2005b), Sansone (1996, 2004), eentre outros.

${ }^{17}$ Sobre esse ponto, ver o debate na revista Horizontes Antropológicos de n. 23, de jan./jun. 2005. 
tas, ${ }^{18}$ a partir do exemplo do estado de Sergipe, onde uma forte identificação com a figura mítica do sertanejo torna os discursos militantes de valorização da identidade negra de difícil aceitação. O que significa dizer que não apenas as realidades regionais são diferentes em termos de composição da população (estados como Bahia e Sergipe, por exemplo, têm cerca $80 \%$ de sua população composta por pretos e pardos, enquanto nos estados do Sul-Sudeste essa percentagem está abaixo de 30\%), mas também em termos de auto-representação. Com isso, em estados que, apesar de uma forte proporção de negros e pardos, a identificação em termos raciais é pouco difundida, como em Sergipe, a aceitação das cotas tende a ser menor que em estados onde a presença de discursos racializadores é mais forte.

Contudo, além dessas questões, acreditamos que a discussão em termos de percepções sociais da justiça pode ampliar nossa compreensão dos resultados obtidos. Um dado que nos pode ajudar a compreender esse fenômeno é a aceitação das cotas para deficientes físicos em empregos públicos. Ou seja, as cotas tendem a ser consideradas mais justas quando aplicadas para compensar algum tipo de inferioridade física ou natural do indivíduo, e recusadas para situações de desvantagem social. O que explica, talvez, o fato de que mesmo os universitários negros, em sua maioria, se posicionaram contra as cotas: aceitá-las significaria desvalorizar-se, reconhecer-se inferior, com menos mérito individual que outros. Visão mais presente entre os que já entraram na universidade do que entre os pré-vestibulandos, que poderão no futuro beneficiar-se das cotas, como mostraram os dados empíricos obtidos.

Esses resultados parecem indicar que as percepções da justiça prevalecentes na sociedade sergipana dizem muito sobre a forma como essa sociedade ava-

${ }^{18}$ Por seu lado, Guimarães (1999) chama a atenção para o fato de que as diferenças de interpretações desenvolvidas pelos intelectuais do Nordeste e os do Sudeste com relação à questão racial podem ser imputadas a realidades diferentes concernentes a relações raciais. lia a questão das PAA. As cotas, vistas como pertinentes apenas para os deficientes, tornam-se iguais a dádivas, benesses ou esmolas, ligadas ao sentimento da compaixão e não à justiça redistributiva. Na prática isso significa que as medidas discricionárias aceitas são apenas as que se destinam a pessoas julgadas com grandes deficiências naturais e, pois, incapazes de competir em igualdade de condições. A suposta deficiência dos negros não seria natural, e sim histórica e social, considerada passível de ser vencida com o esforço individual. Dito de outra maneira, diferenças julgadas naturais, vistas como acima da vontade do indivíduo, podem ser compensadas com políticas especiais, mas não as deficiências sociais, fruto de formas organizativas da sociedade.

Esse raciocínio deixa transparecer o sentimento de que não temos culpa da sociedade ser como é. Há aí uma espécie de naturalização do modo de organização da sociedade. Sendo assim, para mudar algo tão arraigado são necessárias grandes transformações, sem que mudanças menores possam ser tentadas. Ou muda-se tudo ou não se muda nada! Isso se traduz no fato de que as desigualdades e diferenças de oportunidades que atingem os negros são reconhecidas, mas não devem dar lugar a medidas específicas; antes, elas devem ser combatidas por políticas universalistas que visem mudar radicalmente a sociedade. Com isso, posterga-se para um futuro não previsível a resolução da injustiça.

Assim, uma hipótese que parece plausível é de que as cotas são recusadas pela maioria pelo fato de serem identificadas com soluções que visam paliar uma deficiência ou incapacidade individual. Nessa perspectiva, as cotas são consideradas injustas, pois, além de falsearem a realidade das capacidades individuais de cada candidato e irem de encontro assim à igualdade de chances, depreciam os seus beneficiários. As cotas seriam uma vergonha para os que delas usufruírem, pois isso seria um atestado de incompetência individual, um estigma que geraria discriminação e conflitos raciais. ${ }^{19}$ Esse argumento reflete o

${ }^{19}$ Argumento que aparece de maneira recorrente nos debates públicos em torno da questão. Ver Fry e Maggie (2002). 
medo de virmos a reproduzir a situação de outros países: por terem sido pensadas para contextos com sistemas bi-raciais (Estados Unidos e África do Sul), as políticas afirmativas seriam inadequadas para sociedades com sistemas multirraciais, em que a fronteira entre as categorias sociais de definição das raças é fluida e passível de negociação. Emblemáticas a esse respeito são as críticas endereçadas à utilização, pela Universidade de Brasília (UnB), de uma comissão para decidir com base em fotografias quem é ou não negro, para decidir quem pode ou não ser beneficiado pelas cotas no vestibular. ${ }^{20}$

Além disso, uma das maiores causas de resistência ao sistema de cotas é o fato de ele visar ao indivíduo em si, e não à coletividade. Ou seja, embora pensadas para solucionar um problema que atinge um grupo específico (os negros), as cotas beneficiam individualmente os negros mais bem preparados do sistema educacional. Ficam de fora, portanto, os negros mais marginalizados, justamente os que mais precisariam da ajuda coletiva e do Estado. No fundo, para os críticos das cotas elas significam certo reconhecimento da impossibilidade de mudanças das condições de vida dos pobres (dos quais os não-brancos são maioria). Nessa perspectiva, as cotas poderiam implicar mobilidade social individual dos negros, mas não mudança social.

As limitações das ações afirmativas são claramente percebidas por esses críticos: elas não visam à mudança da estrutura de classes ou à repartição de renda na sociedade de uma forma mais radical. Elas buscam formar uma elite intelectual e profissional entre os grupos sociais mais desfavorecidos, na esperança de que eles se tornem elementos de mudanças mais profundas.

Mas, não haveria um meio termo entre a recusa das cotas raciais - em geral por se crer que apenas transformações estruturais da sociedade são capazes de resolver a questão do racismo - e a aceitação pas-

${ }^{20}$ Para uma discussão sobre a problemática das cotas na UnB, ver o número especial da revista Horizontes Antropológicos (n. 23, jan./jun. 2005). siva das cotas como a solução, senão ideal, pelo menos viável, para o problema da discriminação e da desigualdade racial?

Talvez já se estejam esboçando soluções nessa direção. A adoção de critérios socioeconômicos na definição das cotas, por exemplo, parece ir nesse sentido. Ao vincular a possibilidade de poder beneficiarse das cotas à baixa condição econômica, está-se implicitamente admitindo que as deficiências individuais das pessoas de baixa renda não são apenas delas, mas de todo o sistema de ensino público no país. Isso parece refletir-se nos dados apresentados pela menor resistência às cotas para estudantes de escolas públicas do que às cotas raciais. As pressões sociais acerca das cotas podem significar uma maior responsabilização do Estado brasileiro nessas questões (embora devamos admitir também que as cotas podem estar se tornando um mero expediente catártico e midiático para as elites estatais: sem investir um centavo na melhoria do ensino público, as cotas transformam-se de repente na "solução" para a desigualdade racial de acesso à educação).

Outro ponto que merece ser considerado é a possibilidade de distanciamento dos negros beneficiados pelas cotas dos seus meios de origem. Esse é um dos fenômenos que alguns autores, tais como Michel Wieviorka (2001), apontam como uma das conseqüências da implantação de cotas nos Estados Unidos. Nos guetos negros, os indivíduos beneficiados com cotas raciais para as universidades e para empregos tendem a mudar-se de local de habitação, limitando o impacto das cotas sobre as populações mais pobres.

Pensar essa questão pode passar, por exemplo, pela implantação de algumas obrigações para os estudantes que se beneficiam com o sistema de cotas. Trabalhos sociais, ou obrigatoriedade de estágio ou trabalho educativo em bairros populares, poderiam ser meios de evitar que esses estudantes se distanciem de suas comunidades de origem; isso poderia ser um meio para que o investimento social nas cotas se traduzisse não só na possibilidade de ascensão social de certos indivíduos, mas também em benefício de grupos populares com menor poder aquisitivo. 
Provavelmente temos aí uma possibilidade de reduzir algumas resistências ao sistema de cotas raciais. A justiça distributiva não pode ser vista como mera caridade. Para ser socialmente aceita, ela deve ser percebida como um meio de melhoria na vida da coletividade. Assim, o benefício que for conferido a um indivíduo deve traduzir-se em melhoria da vida coletiva. Esse foi, por exemplo, o principal argumento na implantação das políticas de bem-estar social nos países europeus ao longo do século XX. Assim, a cada direito adquirido corresponderia uma obrigação com a coletividade (Rosanvallon, 1995), ou seja, as políticas públicas não devem estar pautadas na lógica do favor e da caridade, mas sim na da retribuição. Para alguns, amparados na teoria da dádiva de Mauss, esse seria o modelo para as sociedades contemporâneas vencerem o individualismo extremado em que nos encontramos.

De todo modo, podemos afirmar que as percepções e atitudes em relação às cotas expressam, de forma enviesada, o modelo de sociedade prevalecente entre nós: individualismo, caridade mais valorizada que a eqüidade, percepção da injustiça mas certa naturalização dela, que leva a uma incapacidade em pensar estratégias para combater as fontes das injustiças. Assim, embora nem sempre esteja explícito, o cerne desse debate é essa dicotomia entre ideais igualitários e realidade desigual naturalizada que tem caracterizado a sociedade brasileira desde o século XIX.

Talvez seja exatamente por isso que se criou tanta polêmica e tanta expectativa em torno das cotas. $\mathrm{Na}$ incapacidade de pôr em prática medidas estruturais de combate às desigualdades no país, elas aparecem para alguns homens públicos como uma estratégia viável e acomodatícia dentro das relações de força prevalecentes, as únicas portas de saída para as demandas de combate à discriminação. Ou seja, com a justificativa de que as cotas permitem maiores chances para um número de negros, a sociedade brasileira pode estar postergando medidas que favoreçam a maioria dos negros do país.

Da mesma forma, os que defendem as cotas cor- rem o risco de deslegitimar as medidas universalistas que busquem resolver os problemas de desigualdades. Ao concentrar os esforços nas cotas, sem discutilas dentro de um projeto que vise resolver gradualmente as desigualdades, corre-se o risco de tornar as cotas paliativas de algo que não se pretende ou não se julga ser possível implantar em um futuro próximo. Isso é o que pode explicar a facilidade com que os governos estaduais e federal estão aceitando a idéia das cotas na sociedade. Ora, as cotas, da maneira como estão sendo aplicadas, não implicam um maior compromisso dos governos com a alocação de recursos na educação ou em outros setores que favoreçam os negros.

Desse modo, podemos afirmar que as resistências às cotas podem ser vistas tanto como resistências a uma visão que pretenda modificar o modelo de justiça liberal clássico, pautado apenas nas capacidades individuais, como também uma resistência ao tipo de ação midiática em que as cotas se estão transformando na sociedade brasileira: medidas paliativas que favorecem um número limitado de afrodescendentes sem que as condições de penúria da maioria dos afrodescendentes sejam combatidas. Isso parece indicar que essa discussão só terá fim quando ambas as frentes forem atacadas: seja pela ampliação do debate para fora dos espaços acadêmicos e dos meios políticos, seja pela vinculação clara e efetiva das cotas a políticas que visem resolver os problemas de desigualdades da sociedade brasileira (melhoria do ensino público, ampliação das vagas nas universidades e centros tecnológicos públicos, políticas de bolsas de estudos para alunos carentes etc.).

\section{Referências bibliográficas}

ADORNO, Sérgio. Violência e racismo: discriminação no acesso à justiça penal. In: SCHWARCZ, L. M.; QUEIROZ, R. da S. (Orgs.). Raça e diversidade. São Paulo: EDUSP, 1996. p.255-275. AZEVEDO, Thales de. As elites de cor numa cidade brasileira: um estudo de ascensão social. Salvador: EDUFBA-Empresa Gráfica da Bahia, 1996.

BANTON, Michael. A idéia de raça. Lisboa: Edições 70, 1977. 
BASTIDE, Roger; FERNANDES, Florestan. Brancos $e$ negros em São Paulo. São Paulo: Companhia Editora Nacional, 1959.

BAUMAN, Zigmunt. Comunidade. Rio de Janeiro: Jorge Zahar Editor, 2003.

BOLTANSKI, Luc.; THÉVENOT, Laurent. De la justification: les économies de la grandeur. Paris: Gallimard, 1991.

CARDOSO, Hamilton B. Limites do confronto racial e aspectos da experiência negra do Brasil - reflexões. In: SADER, Emir (Org.). Movimentos sociais na transição democrática. São Paulo: Cortez, 1987. p.82-104.

DIAMOND, Patrick; GIDDENS, Anthony. The new egalitarianism: Economic inequality in the UK. In: (Eds.). The new egalitarianism. Cambridge: Polity Press, 2005. p.101-119.

DOYTCHEVA, Milena. Le multiculturalisme. Paris: La Decouverte, 2005.

DUBET, François. Injustices: l'expérience des inégalités au travail. Paris: Seuil, 2006.

DWORKIN, Ronald. Levando os direitos a sério. São Paulo: Martins, 2002.

FERNANDES, Florestan. O negro no mundo dos brancos. São Paulo: Difusão Européia do Livro, 1966.

FRANÇA, Dalila Xavier; MONTEIRO, Maria Benedita. Identidade racial e preferência em crianças brasileiras de 5 a 10 anos de idade. Psicologia, v. XVI, n. 2, p.293-323, 2002.

FRASER, Nancy. Justice interruptus; critical reflections on the pos-socialist condition. New York/London: Routledge, 1997.

. Rethinking recognition. New Left Review, n. 3, p.107-

120, maio/jun., 2000.

FREYRE, Gilberto. Casa-grande e senzala: formação da família brasileira sob o regime de economia patriarcal. Lisboa: Edição Livros do Brasil (Edição comemorativa de 1983), 1933.

FRY, Peter; MAGGIE, Yvonne. Le débat qui n'a pas eu lieu: les quotas pour les noirs dans les universités brésiliennes. Cahiers $d u$ Brésil Contemporain, n. 49/50, p. 167-182, 2002.

GOMES, Joaquim Barbosa. Ação afirmativa e princípio constitucional da igualdade. Rio de Janeiro: Renovar, 2001.

. O debate constitucional sobre as ações afirmativas.

In: SANTOS, Renato E. dos; LOBATO, Fátima (Orgs.). Ações afirmativas: políticas públicas contra as desigualdades raciais. Rio de Janeiro: DP\&A, 2003. p.15-57.

GUIMARÃES, Antônio Sérgio Alfredo. Racismo e anti-racismo no Brasil. São Paulo: Editora 34, 1999.
HABERMAS, Jurgen. Débat sur la justice politique. Paris: CERF, 1997a. . Direito e democracia. Rio de Janeiro: Tempo Brasileiro, 1997b.

HASENBALG, Carlos. Discriminações e desigualdades raciais no Brasil. Rio de Janeiro: Graal, 1979.

. Race and socioeconomic inequalities in Brazil. In:

FONTAINE, P. M. (Ed.). Race, class and power in Brazil. Los Angeles: University of California, Centre for Afro-American Studies, 1985. p.25-41.

HONNETH, Axel. Recognition and moral obligation. Social Research, v. 64, n. 1, p.16-35, primavera 1997.

. La lutte pour la reconnaissance. Paris: Les Éditions

du CERF, 2000.

INSPIR - Instituto Sindical Interamericano pela Igualdade Racial. Mapa da população negra no mercado de trabalho. São Paulo: Departamento Intersindical de Estatística e Estudos Sócio-Econômicos (DIEESE), 1999.

KYMLICKA, Will. Contemporary political philosophy: an introduction. Oxford: Oxford University Press, 1990.

.Multicultural citizenship. Aliberal theory of minority rights. Oxford: Clarendon Press, 1995.

LOVELL, Peggy. Race, gender, and development in Brazil. Latin American Research Review, n. 29, p.7-35, 1994.

MARX, Karl. A questão judaica. São Paulo, Centauro, 2002.

MOUFFE, Chantal. The return of the political. Londres/New York: Verso, 1991.

On the political. Londres/New York: Routledge, 2005.

MUNANGA, Kabengele. As facetas de um racismo silenciado. In: SCHWARCZ, Lilia Moritz; QUEIROZ, Renato da Silva (Orgs.). Raça e diversidade. São Paulo: EDUSP, 1996. p.213-229.

NASCIMENTO, Abdias; NASCIMENTO, Elisa Larkin. Reflexões sobre o movimento negro no Brasil (1938-1997). In: GUIMARÃES, A. S.; HUNTLEY, L. (Orgs.). Tirando a máscara. Ensaios sobre o racismo no Brasil. São Paulo: Paz e Terra, 2000. p.203234.

NEVES, Paulo Sérgio da Costa. Le faux dilemme brésilien: nationalisme ou modernité? Cahiers du Brésil Contemporain, v. 31, p.5-35, 1997.

A questão negra em Sergipe: visões de militantes e de não-militantes. In: ASSOCIAÇÃO NACIONAL DE PÓS-GRA- 
Percepções de justiça social e atitudes de estudantes pré-vestibulandos e universitários sobre as cotas...

DUAÇÃO E PESQUISA EM CIÊNCIAS SOCIAIS, 23., 2000, Caxambu. Anais... Caxambu: ANPOCS, 2000. 1 CD-ROM.

Raça e região: elementos preliminares de uma discussão. In: GICO, Vânia; SPINELLI, Antônio; VICENTE, Pedro (Org.). As ciências sociais: desafios do milênio. Natal: EDUFRN, 2001. p.174-200.

Luta anti-racista: entre reconhecimento e redistribuição. Revista Brasileira de Ciências Sociais, v. 20, n. 59, p.81$96,2005 a$.

Identité noire et identité nationale dans le Brésil contemporain. Revue Textures, v. 1, n. 16, p.103-110, 2005b. NOGUEIRA, Oracy. Tanto preto quanto branco. São Paulo: Global, 1983.

Preconceito de marca: as relações raciais em Itapetininga. São Paulo: EDUSP, 1998.

OKIN, Susan Moller. Justice, gender and the family. New York: Basic Books, 1989.

PATAI, Daphne. Brazilian women speak. New Brunswick: Rutgers University Press, 1988.

RAMOS, Arthur. O negro brasileiro. São Paulo: Companhia Editora Nacional, 1951.

RAWLS, John. A theory of justice. Oxford: Oxford University Press, 1971.

RORTY, Richard. Achieving our country, leftist thought in twentieth-century America. Cambridge: University Press, 1998.

ROSANVALLON, Pierre. La nouvelle question sociale. Repenser l’État Providence. Paris: Seuil, 1995.

SANDEL, Michael. Liberalism and the limits of justice. Cambridge: Cambridge University Press, 1982.

SANSONE, Lívio. Nem somente preto nem negro: O sistema de classificação racial no Brasil que muda. Afro-Ásia, Salvador, n. 18, p.165-187, 1996.

Negritude sem etnicidade. Rio de Janeiro: Pallas,

2004.

SILVA, Ana Célia da. Desconstruindo a discriminação do negro no livro didático. Salvador: EDUFBA, 2001.

SILVA, Luiz Fernando Martins. Ação afirmativa e cotas para afrodescendentes: algumas considerações sócio-jurídicas. In: SANTOS, Renato Emerson dos; LOBATO, Fátima (Orgs.). Ações afirmativas: políticas públicas contra as desigualdades raciais. Rio de Janeiro: DP\&A, 2003. p.15-57.

SOWELL, Thomas. Affirmative action around the world. An empirical stydy. New Haven/London: Yale University Press, 2004.
TAYLOR, Charles. The sources of the self. Cambridge: Harvard University Press, 1989. . Multiculturalism and the "Politics of Recognition". Princeton: Princeton University Press, 1992.

TURRA, Cleusa; VENTURI, Gustavo. Racismo cordial: a mais completa análise sobre preconceito de cor no Brasil. São Paulo: Ática, 1995.

YOUNG, Iris Marion. Unruly categories: a critique of Nancy Fraser's dual systems theory. New Left Review, n. 222, p.147-160, mar./abr. 1997.

VITA, Álvaro de. Justiça igualitária e seus críticos. São Paulo: UNESP, 2000.

WALZER, Michael. Spheres of justice: a defense of pluralism and equality. Oxford: Blackwell, 1983.

WIEVIORKA, Michel. La différence. Paris: Balland, 2001.

WILSON, William Julius. The declining significance of race: Blacks and changing American institutions. In: CASHMORE, E.; JENNINGS, J. (Eds.) Racism: essential readings. Londres: Sage Publications, 2001. p.188-208.

WOOD, Charles H.; LOVELL, Peggy. Racial inequality and child mortality in Brazil. Social Forces, v. 70, n. 3, p.703-724, 1992.

PAULO SÉRGIO DA COSTA NEVES, doutor em sociologia e ciências sociais pela Université Lumière Lyon2, é professor no Departamento de Ciências Sociais da Universidade Federal de Sergipe, com participação nos Núcleos de Pós-Graduação em Educação e em Ciências Sociais. Tem realizado pesquisas nos últimos anos sobre relações raciais, educação e direitos humanos, cidadania e teorias da justiça. Dentre suas publicações destacam-se: Luta anti-racista: entre reconhecimento e redistribuição (Revista Brasileira de Ciências Sociais, v. 20, n. 59, p.81-96, 2005); Identité noire et identité nationale dans le Brésil contemporain (Revue Textures, v. 1, n. 16, p.103-110, 2005); Polícia e democracia: desafios à educação em direitos humanos (Org.) (Recife: Bagaço, 2002).E-mail: pneves@ufs.br

MARCUS EUGÊNIO OLIVEIRA LIMA, doutor em psicologia social pelo Instituto Superior de Ciências do Trabalho e da Empresa (ISCTE - Portugal), é professor do curso de psicologia e do mestrado em sociologia da Universidade Federal de Sergipe. Coordena o grupo de pesquisa Normas Sociais, Estereótipos, Preconceitos e Racismo, investigando racismo e processos de 
racialização e etnicização das minorias. Dentre suas publicações destacam-se: Estereótipos, preconceitos e discriminação: perspectivas teóricas e metodológicas (Salvador: EDUFBA, 2004); Social values, prejudice and solidarity in European Union (in: European values at the turn of the Millenium. Londres: Brillbooks, 2004. p.139-166); Individualismo meritocrático, diferenciação cultural e racismo (Análise Social, Lisboa, v. XXXVII, n. 162, p.181-207, 2002).E-mail: meolima@uol.com.br

Recebido em agosto de 2006 Aprovado em novembro de 2006 


\section{Resumos/Abstracts/Resumens}

Paulo S. C. Neves e

Marcus Eugênio O. Lima

\section{Percepções de justiça social e} atitudes de estudantes prévestibulandos e universitários sobre as cotas para negros e pardos nas universidades públicas

Um dado novo nas relações racializadas no Brasil nos últimos anos tem sido o das políticas de ação afirmativa para minorias étnicas. A política de cotas de acesso para negros e pardos nas universidades públicas tem gerado um intenso debate sobre questões de discriminação e de identidade racial que antes não pareciam pertinentes no país que possui a maior população negra vivendo fora da África. A fim de analisarmos a relação entre as percepções de justiça social e os posicionamentos de estudantes sobre as cotas, realizamos dois estudos em Aracaju envolvendo estudantes de dois cursinhos pré-vestibulares (um público e um privado) e estudantes de todos os cursos da Universidade Federal de Sergipe. Os resultados indicam forte rejeição às cotas, sobretudo na universidade. Pensamos que essa resistência pode indicar tanto uma recusa a uma transformação do modelo de justiça liberal, pautado no mérito individual, quanto uma resistência ao tipo de ação apenas midiática em que as cotas se estão transformando na sociedade brasileira.

Palavras-chave: justiça social; cotas e atitudes

Perceptions of social justice and attitudes of candidates for university places and university students about quotas for Negroes and coloureds in public universities

In the last few years, a new element in racial relations in Brazil has been the affirmative action policy for ethnic minorities. The policy of quotas for Negroes and coloureds in public universities has brought to the surface an intense debate on discrimination and issues of racial identity which had not seemed relevant before, in the country that holds the largest black population outside of Africa. The purpose of this work is to analyse the relation between the perceptions of social justice and the attitudes of students towards the policy of quotas. To this end, we carried out two studies in the city of Aracaju with candidates for university places from two courses (a public and a private school) and students from all courses at the Federal University of Sergipe.

The results revealed a strong rejection of quotas, mainly in the university context. We suppose that this resistance can be seen both as an affirmation of the model of liberal justice, based on individual merit, and a reaction to the type of merely newsworthy action in which quotas are being transformed in Brazilian society.

Key words: social justice; quotas and attitudes

Percepciones de justicia social y actitudes de estudiantes prevestibulandos y universitarios sobre las cuotas para negros y pardos en las universidades públicas

Un dato nuevo en las relaciones 
raciales en Brasil en los últimos años ha sido el de las políticas de acción afirmativa para minorías étnicas. La política de cuotas de ingreso para negros y pardos en las universidades públicas ha generado un intenso debate sobre cuestiones de discriminación y de identidad racial que antes no parecían pertenecer al país que posee la mayor población negra viviendo fuera de África. Con el propósito de analizar la relación entre las percepciones de justicia social y los posiciomanientos de estudiantes sobre las cuotas, realizamos dos estudios en Aracaju envolviendo estudiantes de dos cursos de pre-vestibulares (uno público y otro privado) y estudiantes de todos los cursos de la Universidad Federal de Sergipe. Los resultados indican un fuerte rechazo a las cuotas, sobretodo en la universidad. Pensamos que esta resistencia puede indicar tanto una recusa a una transformación del modelo de justicia liberal, pautado en el mérito individual, cuanto una recusa al tipo de acción solamente mediadora en que las cuotas se están transformando en la sociedad brasileña.

Palabras claves: justicia social; cuotas yactitudes 